\title{
A guideline for the appointment, promotion, and tenure of academic librarians
} Approved at ALA Annual Conference, June 2005

\section{Introduction}

This guideline for appointment, promotion, and tenure is intended for use where librarians have faculty status. It is intended for application within the context of two ACRL policy statements on faculty status for academic librarians, ${ }^{1}$ as well as related statements issued by the American Association of University Professors. ${ }^{2}$

The objective of this guideline is to propose criteria and procedures for appointment, promotion in academic rank, and tenure (continuous appointment) for use in academic libraries. Using these criteria and procedures will ensure that the library faculty (and, therefore, library services) will be of the highest quality possible. These criteria are intended to be minimal only. These procedures may need to be adjusted in minor detail to conform with existing institutional procedures for other faculty. Any contractual procedures must be observed.

\section{Appointment}

\section{A. General policies}

1. Appointment of librarians shall follow the same procedures that are established for appointing all institutional faculty members. Any librarian appointed to a college or university library faculty shall have the appropriate terminal professional degree. ${ }^{3}$ Appointment to any rank shall meet the criteria appropriate to that rank.

2. To ensure that only candidates of the highest quality are appointed to the library faculty, there shall be a committee represen- tative of the library faculty selected to review and screen all candidates, participate in the interview process, and make recommendations for appointment.

3. The terms and conditions of every appointment to the library faculty shall be stated and con rmed in writing, and copies of all relevant documents, including the of cial document of appointment, shall be given to the faculty member. Subsequent extensions or modi cations of an appointment shall be stated and con rmed in writing.

\section{B. Probationary appointments}

1. Probationary appointments may be for no less than one year, or for other stated periods longer than a year, subject to renewal. The total period of full-time service prior to acquiring tenure shall not exceed seven years, and may include previous full-time service with the rank of instructor or higher in other institutions of higher learning (except that the probationary period may extend to as much as four years, even if the total full-time service in the profession thereby exceeds seven years; the terms of such extension shall be stated in writing at the time of initial appointment). Scholarly leave of absence for one year or less shall count as part of the probationary period as if it were prior service at another institution, unless the individual and the institution agree in writing to an exception to this provision at the time the leave is granted.

2. The faculty member shall be advised at the time of initial appointment of the substantive standards and procedures employed 


\section{About the Guidelines}

These guidelines are a revision of the Model statement of criteria and procedures for appointment, promotion in academic rank and tenure for college and university librarians rst issued by ACRL in 1973 and revised in 1987.

The ACRL Board charged the Committee on the Status of Academic Librarians with the task of revising this document. The revision process began in January 2003 under the chairmanship of Bill Nelson, Augusta State University. The nal revision was completed under the chairmanship of Sharon McCaslin, Fontbonne University, with a draft published in the April 2005 issue of CERL News.

Following the recommendation of the ACRL Standards and Accreditation Committee (SAC), the title was changed so that guidelines replaced model statement. The guidelines were approved by SAC and subsequently approved by the ACRL Board in June 2005. The previous model statement was rescinded.
Members of the ACRL Committee on the Status of Academic Librarians who conducted this revision were: Carolyn Allen, University of Arkansas; Navjit Brar, California Polytechic State University; Theresa Byrd, Ohio Wesleyan University; Jim Chervinko, Southern Illinois University-Carbondale; Betina Gardner, Eastern Kentucky University; Todd Gilman, Yale University; Suzanne Graham, University of Southern Mississippi; Phillip Jones, University of Arkansas; Sharon McCaslin, Fontbonne University; Bill Nelson, Augusta State University; Samson Soong, Hong Kong University of Science and Technology; Sr. Anita Talar, Seton Hall University; Leanne VandeCreek, Northern Illinois University; Ravil Veli, Plattsburgh State University of New York; Joleen Westerdale, Washington University; Lisa Williams, University of North Carolina at Wilmington; Corey Williams-Green, University of Maryland-Baltimore County; Rebecca Ziegler, Georgia Southern University. in decisions affecting renewal and tenure. Institutional standards should be clearly identi ed, as well as any special standards adopted by the library. The faculty member shall be advised of the time when decisions affecting renewal or tenure are made.

3. The institution shall normally notify faculty members of the terms and conditions of their renewals by March 15 or three months before the new contract begins.

4 . Written notice that probationary appointment is not to be renewed shall be given to the faculty member in advance of the expiration of the appointment, as follows:

\begin{tabular}{l|l}
$\begin{array}{l}\text { Length of probationary } \\
\text { appointment }\end{array}$ & Written notice given \\
\hline One year & $\begin{array}{l}\text { March 1st or at least three months before } \\
\text { end of rst year of probationary service }\end{array}$ \\
\hline $\begin{array}{l}\text { Initial two-year } \\
\text { appointment }\end{array}$ & $\begin{array}{l}\text { December 15th or at least six months in } \\
\text { advance of termination }\end{array}$ \\
\hline $\begin{array}{l}\text { Two or more years of } \\
\text { service }\end{array}$ & $\begin{array}{l}\text { At least one year in advance of termination } \\
\text { October } 2005\end{array}$
\end{tabular}

5. When a faculty recommendation or a decision not to renew an appointment has rst been reached, the faculty member involved shall be informed of that recommendation or decision in writing by the body or individual making the initial recommendation or decision; the faculty member shall be advised upon request of the reasons that contributed to that decision. The faculty member may request reconsideration by the recommending or deciding body.

6. If the faculty member so requests, the reasons given in explanation of the non-renewal shall be con rmed in writing.

7. Should the faculty member allege that the decision against renewal was based on unfairness, the committee that reviews the faculty member $s$ allegation shall determine whether the 
decision was fair in terms of the relevant standards of the institution. The review committee shall not substitute its judgment on the merits for that of the faculty body. If the review committee determines that adequate consideration was not given, it shall request reconsideration by the faculty body, indicating the respects in which it believes the consideration may have been inadequate. It shall provide copies of its ndings to the faculty member, the faculty body, and the chief executive of cer or other appropriate administrative of cer.

\section{Promotion in academic rank A. General professional and scholarly qualifications of the library faculty}

All activities shall be judged by professional colleagues on and/or off the campus on the basis of their contribution to scholarship, the profession of librarianship, and library service. The basic criterion for promotion in academic rank is to perform professional level tasks that contribute to the educational and research mission of the institution.

Evidence of this level of performance may be judged by colleagues on the library faculty, members of the academic community outside the library, and/or professional colleagues outside the academic institution.

Additional evidence for promotion in rank may include:

1. Contributions to the educational mission of the institution: for example, teaching (not necessarily in a classroom); organization of workshops, institutes, or similar meetings; public appearances in the interest of librarianship or information transfer. Assessment by students and professional colleagues may contribute to this evaluation.

2. Contributions to the advancement of the profession: for example, active participation in professional and learned societies as a member.

3. Activities related to inquiry and research: for example, scholarly publication, presentation of papers, reviews of books and other literature, grants, consulting, service as a member of a team of experts, or other means of disseminating professional expertise.

\section{B. Criteria for promotion to specific ranks}

Promotion to the ranks of assistant professor, associate professor, and professor requires a record of successful ful llment of criteria at the lower level.

Instructor Appointments at this rank shall require expectation of successful overall performance and the potential for a promising career in librarianship. Institutional practice for faculty appointments varies. Specialized skills or expertise may justify appointment at a higher rank.

Assistant professor Promotion to this rank shall require evidence of signi cant professional contributions to the library or to the institution.

Associate professor Promotion to this rank shall require evidence of substantial professional contributions to the library and to the institution, as well as attainment of a high level in research or other professional endeavors.

Professor Promotion to this rank shall require outstanding achievements in librarianship, research, and other professional endeavors.

\section{Procedures for promotion to spe- cific ranks}

1. Candidates for promotion in academic rank shall be considered by a peer review committee formed in accordance with appropriate institutional regulations.

2. Recommendations for promotion in academic rank may be made by the appropriate administrator, or a member of the library faculty, who shall give the candidate copies of any recommendations or evaluations. These statements shall be retained.

3. Documentation in support of candidates for promotion in rank shall include 
evaluations from the appropriate administrator. Additional documentation may include letters from colleagues, copies and reviews of publications, records of committee activity, etc.

4. The peer review committee (see C-1) shall transmit its recommendations, with all supporting documentation, to the chief administrative of cer of the library.

5. The chief administrative of cer of the library will receive the recommendations of the committee, make a decision, and so notify the committee. If the chief administrative of cer of the library does not concur in any particular recommendation, after consultation with the committee, he/she may note such disagreement before notifying the candidate of the recommendations. The chief administrative of cer of the library shall inform the committee and the candidate in writing of the recommendations before transmitting the recommendations of the committee and the chief administrative of cer of the library to the appropriate institutional of cer. The candidate then will have the opportunity to respond in writing to the recommendations. After this, the chief administrative of cer of the library will submit his/her recommendation, the recommendation of the committee, and any responses from these parties or from the candidate to the appropriate institutional of cer.

6. If the candidate for promotion believes there are substantial grounds for disagreement with a denial of promotion, appropriate institutional regulations shall be provided so that the case may be properly reviewed. The unsuccessful candidate may le a grievance as speci ed in Section V.

\section{Tenure (continuous appointment)}

A. Tenure, or continuous appointment, is de ned as an institutional commitment to permanent employment to be terminated only for adequate cause (for example, incompetence, malfeasance, mental or physical disability, bona de nancial exigency) and only after due process. Tenure (continuous appointment) shall be available to librarians in accordance with provisions for all faculty of the institution.

\section{B. The criteria for tenure are closely} allied to the criteria for promotion in academic rank. The relationship between tenure and rank shall be the same for library faculty as for other faculty in the institution. These criteria include performance, scholarship, and service.

C. A candidate for tenure shall be reviewed according to established institutional regulations, which shall be similar to those described above for promotion in academic rank.

\section{Termination of appointments}

A. Termination of appointment by the individual

Faculty members may terminate their appointments, provided they give notice in writing at the earliest possible opportunity, or within 30 days after receiving noti cation of the terms of appointment for the coming year. Faculty members may properly request a waiver of this requirement of notice in case of hardship or in a situation where they would otherwise be denied substantial professional advancement.

\section{B. Termination of appointment by the institution}

1. Termination of an appointment with continuous tenure, or of a probationary or special appointment before the end of the speci ed term, may be effected by the institution only for adequate cause.

2. If termination takes the form of a dismissal for cause, it shall be pursuant to the procedure speci ed in section VI below.

3. Financial exigency

a. Termination of an appointment with continuous tenure, or of a probationary or special appointment before the end of the speci ed term, may occur under extraordinary circumstances because of a demonstrably bona de nancial exigency (an imminent nancial crisis that threatens the 
survival of the institution as a whole and cannot be alleviated by less drastic means).

When adopting regulations on nancial exigency, each institution will need to decide how to allocate the necessary hard decisions. The institution shall appoint a representative faculty body to participate in determining that a condition of nancial exigency exists or is imminent, and that all feasible alternatives to termination of appointments have been pursued.

The termination of appointments involves consideration of all educational programs and policy, including af rmative action and faculty status. These determinations should be the primary responsibility of an appropriate faculty body. The faculty or an appropriate faculty body shall also exercise primary responsibility in determining the criteria for identifying the individuals whose appointments are to be terminated. The criteria may appropriately include considerations of age and of length service.

The faculty should designate or approve the group or person who is responsible for selecting the individuals whose appointments are to be terminated. The allocation of this responsibility may vary according to the size and character of the institution, the extent of the terminations to be made, or other considerations. The case of a faculty member given notice of proposed termination of appointment will be governed by the following procedure.

b. If the administration issues notice of an intention to terminate the appointment of a particular faculty member because of nancial exigency, the faculty member shall have the right to a full hearing before a faculty committee. The hearing need not conform in all respects with a proceeding conducted pursuant to Section VI, but the essentials of an on-the-record adjudicative hearing shall be observed. The issues in this hearing may include:

i. The existence and extent of the condition of nancial exigency (The burden will rest on the administration to prove the existence and extent of the condition. The ndings of a faculty committee in a previous proceeding on this issue may be introduced.);

ii. The validity of the educational judgments and the criteria for identication for termination (The recommendations of the faculty body should be accepted.);

iii. Whether the criteria are being properly applied in the individual case.

c. If the institution terminates appointments because of nancial exigency, it shall not make new appointments at the same time except in extraordinary circumstances. The appointment of a faculty member with tenure should not be terminated in favor of retaining a faculty member without tenure, except in extraordinary circumstances.

d. Before terminating an appointment because of nancial exigency, the institution, with faculty participation, shall make every effort to place the faculty member concerned in another suitable position within the institution.

e. In all cases of termination of appointment because of nancial exigency, the faculty member concerned shall be given notice or severance salary not less than as prescribed in Section IX.

$f$. In all cases of termination of appointment because of nancial exigency, the place of the faculty member concerned shall not be lled by a replacement within a period of three years, unless the released faculty member has been offered reinstatement.

4. Discontinuation of a program or department not mandated by financial exigency

Termination of an appointment with continuous tenure, or a probationary or special appointment before the end of the speci ed term, may occur as a result of bona de formal discontinuance of a program or department of instruction. The following standards and procedures shall apply:

a. The decision to discontinue formally a library unit, department, or function shall 
be based essentially upon educational considerations as determined primarily by the faculty as a whole or an appropriate committee thereof. Note: Educational considerations do not include cyclical or temporary variations in enrollment. They must re ect long-range judgments that the educational mission of the institution as a whole will be enhanced by the discontinuance.

b. Before the administration issues notice to a faculty member of its intention to terminate an appointment because of formal discontinuance of a library unit, department, or function, the institution shall make every effort to place the faculty member in another suitable position and offer a reasonable period of training at the institution s expense. If no position is available within the institution, the faculty member s appointment then may be terminated, but only with provision for severance salary equitably adjusted to the faculty member s length of past and potential service.

c. A faculty member may appeal a proposed relocation or termination resulting from discontinuance and has a right to a full hearing before a faculty committee. In such a hearing a faculty determination that a program or department is to be discontinued should be accepted, but the burden of proof on other issues shall rest on the administration.

5. Termination for medical reasons

Termination of an appointment with tenure, or of a probationary or special appointment before the end of the period of appointment, for medical reasons, shall be based upon medical evidence that the faculty member cannot continue to ful 11 the terms of the appointment. Sick leave or disability status should be used whenever possible. The decision to terminate shall be reached only after there has been appropriate consultation and after the faculty member, or someone representing the faculty member, has been informed of the proposed action and has an opportunity to respond to the evidence. If the faculty member so requests, the appropriate committee shall review the evidence before the institutional governing board makes a nal decision on the recommendation of the administration. The faculty member shall be given severance salary not less than that prescribed in Section IX.

6. Review

In case of termination of appointment, the governing board shall be available for ultimate review.

\section{Grievance}

In the event that an amicable solution cannot be reached between the two parties, a grievance procedure shall be provided by the institution. The general criteria for a grievance procedure include:

\section{A. The procedure shall be equitable} to both parties.

B. The procedure shall state clearly what is to be done, when, and by whom.

C. The term grievance, as well as any other terms that could be misunderstood, shall be clearly de ned.

D. The procedures should be accessible to and easy to initiate by all members of the library faculty.

E. Steps in the procedure shall be completed within speci ed time limits. Additional time shall be allowed as the grievance moves to higher levels.

\section{F. There shall be effective safeguards} against reprisal for initiating or participating in a grievance proceeding and against abuse of the procedures.

G. Any procedure must be consistent with applicable institutional regulations and contracts.

\section{Dismissal procedures}

A. Adequate cause for a dismissal shall be related, directly and substantially, to the tness of faculty members in their 
professional capacities as librarians. Dismissal shall not be used to restrain faculty members in their exercise of academic freedom.

B. Dismissal of a faculty member with continuous tenure, or with a special or probationary appointment before the end of the speci ed term, shall be preceded by:

1. Discussions between the faculty member and appropriate administrative of cers looking toward a mutual settlement;

2. Inquiry by the duly elected faculty committee that will make a non-binding recommendation to continue or cancel dismissal proceedings; and

3. A statement of charges, framed by the chief executive of cer or the CEO s delegate.

\section{A dismissal procedure should in-}

clude a written statement of adequate cause. The individual concerned shall have the right to address the elected faculty hearing committee.

1. Pending a nal decision by the hearing committee, the faculty member shall be assigned to other duties in lieu of suspension, and suspended only if his/her continued presence poses a signi cant danger.

2. The hearing committee may, with the consent of the parties concerned, hold joint prehearing meetings with the parties to stipulate the facts, provide for the exchange of documentary or other information, and achieve other appropriate prehearing objectives to make the hearing fair, effective, and expeditious.

3. The faculty member may waive a hearing or may respond to the charges in writing at any time before the hearing. If the faculty member waives a hearing, the committee shall evaluate all available evidence and submit its recommendation upon the evidence in the record.

4. The committee in consultation with the chief executive of cer and the faculty member shall determine whether the hearing shall be public or private.
5. During the proceedings, the faculty member shall be permitted to have an academic advisor and counsel of the faculty member s choice.

6. At the request of either party or the hearing committee, a representative of a responsible educational association shall be permitted to attend the proceedings as an observer.

7. A verbatim record of all hearings shall be taken and a copy made available to the faculty member without cost, on request.

8. The burden of proving adequate cause rests with the institution and shall be satis ed only by clear and convincing evidence in the record considered as a whole.

9. The faculty member shall have the opportunity to obtain necessary witnesses, documentation, or other evidence. The administration shall cooperate with the hearing committee in securing witnesses, documentation, and other evidence.

10. The faculty member and the administration shall have the right to confront and cross-examine all witnesses. When the witnesses cannot or shall not appear, but the committee determines that the interests of justice require admission of their statements, the committee shall identify the witnesses, disclose their statements, and, if possible, provide for interrogatories.

11. In the hearing of charges of incompetence, the testimony shall include that of quali ed librarians.

12. The hearing committee shall not be bound by strict rules of legal evidence. It may admit any evidence that is of probative value in determining the issues. Every possible effort shall be made to obtain the most reliable evidence.

13. The ndings of fact and the decision shall be based solely on the hearing record.

14. Except for simple necessary announcements that cover the time of the hearing and similar matters, all parties shall avoid public statements and publicity about 
the case until the proceedings have been completed.

15. If the hearing committee concludes that adequate cause for dismissal has not been established by the evidence in the record, it shall so report to the president. If the president rejects the report, the president shall state the reasons for doing so, in writing, to the hearing committee and to the faculty member, and shall provide an opportunity for response before transmitting the case to the governing board. If the hearing committee concludes that an academic penalty less than dismissal is more appropriate, it shall so recommend with supporting reasons.

\section{Action by the institutional govern- ing board}

If dismissal or other severe sanction is recommended, the president shall, on request of the faculty member, transmit the record of the case to the governing board. The governing boards review shall be based on the record of the committee hearing. This review shall provide opportunity for the principals or their representatives to make oral and/or written argument. The governing boards shall either sustain the decision of the hearing committee or return the ndings to the committee with speci $\mathrm{c}$ objections. The committee shall then reconsider, taking into account these objections and receiving new evidence, if necessary. The governing board shall make a final decision only after study of the committee $s$ reconsideration.

\section{Procedures for imposition of sanc- tions other than dismissal}

\section{A. If the administration believes that}

the conduct of a faculty member does not constitute adequate cause for dismissal, but is sufficiently grave to justify imposition of a severe sanction, such as suspension from service for a stated period, the administration may institute a proceeding to impose such a severe sanction. The procedures outlined in Section VI shall govern such a proceeding.

\section{B. If the administration believes that}

the conduct of a faculty member justi es the imposition of a minor sanction, such as a reprimand, it shall notify the faculty member of the basis of the proposed sanction. The faculty member shall have an opportunity to persuade the administration that the proposed sanction not be imposed. A faculty member who believes that a major or minor sanction has been incorrectly imposed may, pursuant to Section $\mathrm{V}$, petition the faculty grievance committee for such action as may be appropriate.

\section{Terminal salary or notice}

If the appointment is terminated, the faculty member shall receive salary or notice in accordance with the following schedule:

\begin{tabular}{l|l|l}
$\begin{array}{l}\text { Length of } \\
\text { probationary } \\
\text { service }\end{array}$ & $\begin{array}{l}\text { Final decision } \\
\text { reached by }\end{array}$ & Notice given \\
\hline $\begin{array}{l}\text { Less than } 9 \\
\text { months }\end{array}$ & March 1 & $\begin{array}{l}\text { Three months } \\
\text { before end of } \\
\text { rst year of } \\
\text { probationary } \\
\text { service }\end{array}$ \\
\hline $\begin{array}{l}\text { Between } 9 \text { and } \\
18 \text { months }\end{array}$ & December 15 & $\begin{array}{l}\text { At least six } \\
\text { months }\end{array}$ \\
\hline $\begin{array}{l}\text { Over } 18 \text { months } \\
\text { or member has } \\
\text { tenure }\end{array}$ & $\begin{array}{l}\text { After } 18 \text { months } \\
\text { of service }\end{array}$ & $\begin{array}{l}\text { At least one } \\
\text { year }\end{array}$ \\
\hline
\end{tabular}

This provision for terminal notice or salary need not apply in the event that there has been a nding that the conduct, which justi ed dismissal, involved malfeasance. On the recommendation of the faculty hearing committee or the chief executive of cer, the governing board may take into account the length and quality of service of the faculty member in determining what, if any, payments shall be made beyond the effective date of dismissal.

\section{Academic freedom and protection against discrimination}

All members of the faculty, whether ten- 
ured or not, are entitled to academic freedom as set forth in the 1940 Statement of principles on academic freedom and tenure, formulated by the Association of American Colleges and the American Association of University Professors.

All members of the faculty, whether tenured or not, are entitled to protection against illegal or unconstitutional discrimination by the institution, or discrimination on a basis not demonstrably related to the faculty member s professional performance, including, but not limited to, race, sex, religion, national origin, age, physical handicap, marital status, or sexual preference.

\section{Complaints of violation of academic freedom or of discrimination in non- reappointment}

If a faculty member on probationary or other non-tenured appointment alleges that a decision against reappointment was based signi cantly on considerations that violate either academic freedom or policies of nondiscrimination with respect to race, sex, religion, national origin, age, physical handicap, marital status, or sexual preference, the allegation shall be rst considered by the appropriate committee. This committee shall try to settle the matter by informal methods. The allegation of violation shall be accompanied by the faculty member s statement consenting to the institution s presentation of supporting evidence to the committee. An unresolved matter shall be heard in the manner set forth in Sections VI and VII, except that the faculty member making the complaint is responsible for stating the grounds upon which the allegations of violation are based, and the burden of proof shall rest upon the faculty member. If the faculty member succeeds in establishing a prima facie case, it is incumbent upon those who made the decision against reappointment to present evidence in support of the decision. Statistical evidence of improper discrimination may be used in establishing a prima facie case.

\section{Administrative personnel}

The foregoing regulations apply to administrative personnel who hold academic rank, but only in their capacity as faculty members. The procedures set forth in Section XI apply to termination or nonreappointment to an administrative post. Administrators who allege a violation of academic freedom or of governing policies against improper discrimination are entitled to these procedures.

\section{Notes}

1. Standards for faculty status for college and university librarians, approved by ACRL and ALA, January 2001 (www.ala.org/ala /acrl/acrlstandards/standardsfaculty.htm); Joint statement on faculty status of college and university librarians, drafted by a committee of the Association of American Colleges (AAC), the American Association of University Professors (AAUP), and ACRL; endorsed by ACRL, June 1972, and by AAUP, April 1973. Reaf rmed by ACRL, June 2001 (www.ala.org/ala/acrl /acrlstandards/jointstatementfaculty.htm).

2. Recommended Institutional Regulations on Academic Freedom and Tenure (www.aaup.org/statements/Redbook/RBrir. htm). Much of the original Model statement was drawn from earlier versions of this statement.

3. See the ACRL Statement on the terminal professional degree for academic librarians (www.ala.org/ala/acrl/acrlstandards /statementterminal.htm). $\boldsymbol{z}$

\section{Standards and guidelines on the Web}

ACRL promulgates standards and guidelines to help libraries, academic institutions, and accrediting agencies understand the components of an excellent library. ACRL standards and guidelines can be found on the ACRL Web site at www.ala.org/ala/acrl/acrlstandards /standardsguidelines.htm.Tam ina, nes 